\title{
Electrolyte and Fluid Transport in Mesothelial Cells
}

\author{
Hong-Long Ji* and Hong-Guang Nie
}

\author{
Department of Biochemistry, Texas Lung Injury Institute, University of Texas Health Science Center at Tyler, Tyler, TX \\ 75708, USA
}

\begin{abstract}
Mesothelial cells are specialized epithelial cells, which line the pleural, pericardial, and peritoneal cavities. Accumulating evidence suggests that the monolayer of mesothelial cells is permeable to electrolyte and fluid, and thereby govern both fluid secretion and re-absorption in the serosal cavities. Disorders in these salt and fluid transport systems may be fundamental in the pathogenesis of pleural effusion, pericardial effusion, and ascites. In this review, we discuss the location, physiological function, and regulation of active transport $\left(\mathrm{Na}^{+}-\mathrm{K}^{+}\right.$-ATPase $)$systems, cation and anion channels $\left(\mathrm{Na}^{+}, \mathrm{K}^{+}, \mathrm{Cl}^{-}\right.$, and $\mathrm{Ca}^{2+}$ channels), antiport (exchangers) systems, and symport (co-transporters) systems, and water channels (aquaporins). These secretive and absorptive pathways across mesothelial monolayer cells for electrolytes and fluid may provide pivotal therapeutical targets for novel clinical intervention in edematous diseases of serous cavities.
\end{abstract}

Key words: mesothelioma, ion channel, permeability, effusion, filtration, $\mathrm{ENaC}$.

Mesothelial cells are specialized epithelial cells that line the serous cavities, including the pleural, pericardial, and peritoneal cavities in addition to internal organs [1]. While the mesothelium was first described more than a century ago, one of its critical essential functions, namely, its active roles in transerosal transport, in particular, cavity fluid secretion and re-absorption, was long overlooked. Only in last two decades compelling evidence accumulated that mesothelial cells actively transport electrolytes and fluid and, in turn, regulate liquid volume within the cavities. The mesothelium, on the basis of recent increasing experimental evidence, both in vitro and in vivo, is less permeable to electrolytes than was previously assumed, with ion permeability characteristics similar to those in epithelia [2,3]. Herein this article we will review the expression and biophysical features of salt and fluid transport systems, both active and passive, that have been identified in mesothelial cells (Fig. 1, Tables $\mathbf{1}$ and $\mathbf{2}$ ).

\section{ION CHANNELS AND ATPASE}

\section{I-1. Amiloride-Inhibitable Cation Channels}

The epithelial sodium channel (ENaC), as a major pathway which participates in sodium movement across the apical membrane of polarized epithelial cells, has been cloned and characterized [4-6]. The members of the ENaC/DEG gene family show a high degree of functional heterogeneity that is unusual among other known ion channel gene families. Five $\mathrm{ENaC}$ subunits have been cloned to date, namely $\alpha-, \beta-, \gamma-, \delta-$, and $\varepsilon$-ENaC [7]. The biophysical properties of various $\mathrm{ENaC}$ channels depend on their subunit compositions. When expressed in oocytes one of "conductive"

\footnotetext{
*Address correspondence to the author at the Department of Biochemistry, University of Texas Health Science Center at Tyler, 11937 US Highway 271, BMR 604, Tyler, TX 75708, USA; Tel: 903.877.7418; Fax: 903.877.5438; E-mail: james.ji@uthct.edu

${ }^{\#}$ Dr. Hong-Guang Nie is a visiting scientist from the School of Pharmaceutical Sciences, China Medical University, Liaoning, Shenyang 110001, China; E-mail: hg.nie@uthct.edu
}

subunits $(\alpha, \delta$, and $\varepsilon$-ENaC) can form a channel sharing identical biophysical properties to three-subunit channels composed of both a "conductive" subunit and two "nonconductive" subunits, namely, $\beta$ - and $\gamma$ - ENaCs. When $\alpha$-, $\beta-$, and $\gamma-\mathrm{ENaC}$ subunits are assembled together, the result is a 4- to 6-pS channel that is highly selective for $\mathrm{Na}^{+}$over $\mathrm{K}^{+}$. In contrast, two-subunit $\alpha \beta-$ and $\alpha \gamma-\mathrm{ENaC}$ channels display diverse amiloride sensitivity, conductance, and $\mathrm{Na}^{+}$permeability [8]. $\mathrm{ENaC}$ is expressed in epithelial cells of several tissues and is involved in salt and water reabsorption [9]. Diuretic amiloride inhibits $\mathrm{Na}^{+}$transport when added to the solution bathing the apical plasma membrane, at a concentration of $10^{-6} \mathrm{M}[10,11]$.

Stefanidis et al. recently showed evidence of amiloridesensitive ion transport in human parietal peritoneal membranes by Ussing chamber studies. The increase in the transmesothelial electrical resistance observed following the addition of amiloride, clearly indicated the probable existence of amiloride-sensitive sodium channels, which may play a role in the ultrafiltration process and sodium removal during peritoneal dialysis [12]. Similarly, Zarogiannis and co-workers investigated the effects of amiloride on the electrical resistance of isolated visceral sheep peritoneum. An increment in the electrical resistance was observed upon addition of amiloride which is further indicative of the expression of an amiloride-sensitive transport in mesothelial cells [13]. Very interestingly, the amiloride-sensitive electrical resistance of the diaphragmatic parietal pleura is significantly higher than that of the costal parietal pleura, suggesting that the costal pleura is more permeable than the diaphragmatic pleura [14]. It is worthy of notice that amiloride exerted its action only on the apical side and not on the basolateral side. By comparison with polarized epithelial cells, it is conceivable to expect that $\mathrm{ENaC}$ proteins are expressed on the serosal side. Unfortunately, these studies did not perform immunofluorescent microscope experiments to locate the subcellular sites of ENaC expression in the pleural mesothelial cells. 


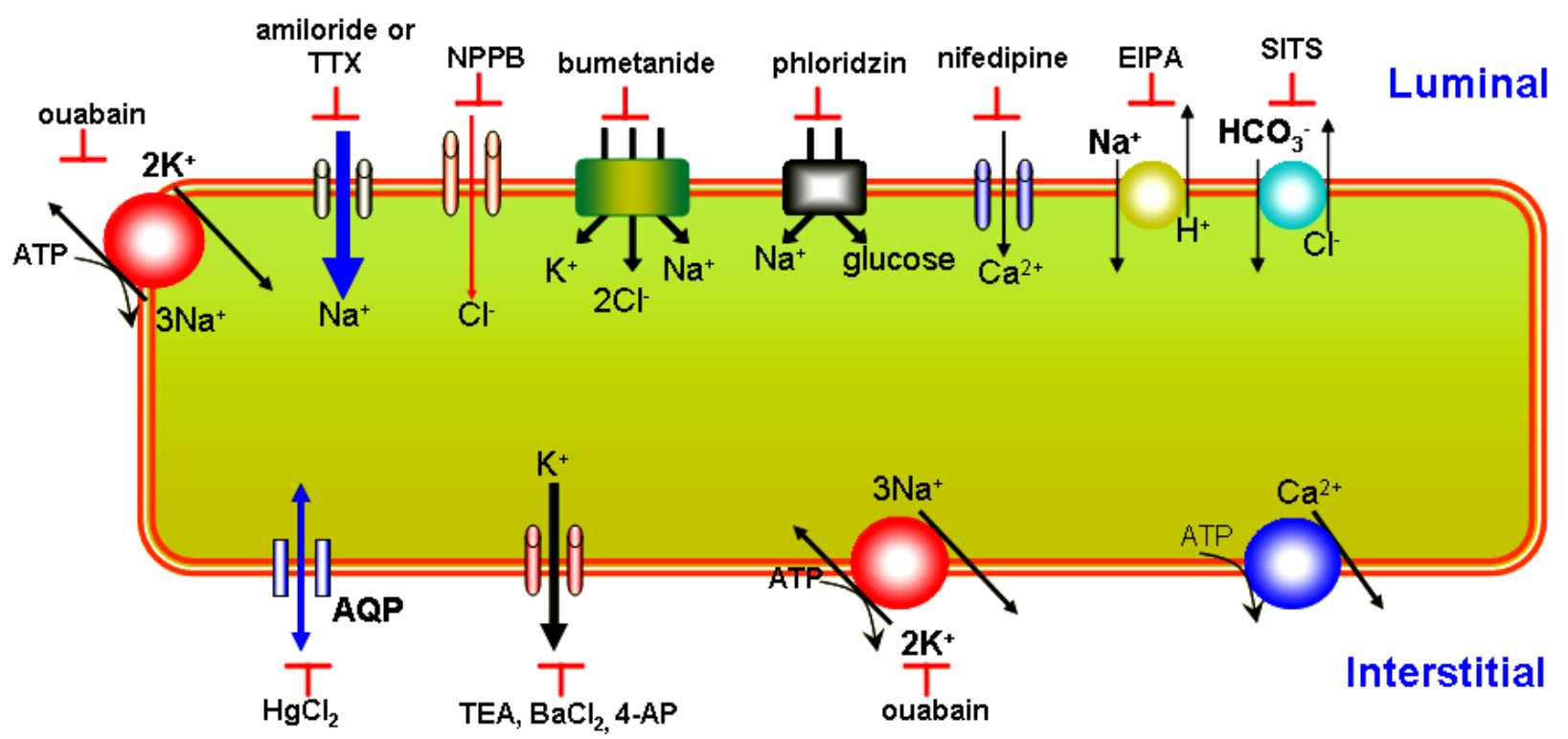

Fig. (1). Electrolyte and fluid transport systems reported in mesothelial cells. The location of ion transport systems is indicated in either the apical or basolateral membrane. The specific inhibitor for each transport pathway is shown. AQP, aquaporins. Please see the legends of Table $\mathbf{1}$ and $\mathbf{2}$ for the full names of other abbreviations.

\section{Table 1. Ion Channels and ATPases in Mesothelial Cells}

\begin{tabular}{|c|c|c|c|c|}
\hline \multirow[t]{4}{*}{$\begin{array}{l}\text { Amiloride-sensitive } \\
\text { transport }\end{array}$} & Human parietal peritoneum & $\begin{array}{l}10^{-3} \text { amil to apical, basolateral } \\
\text { sides }\end{array}$ & Ussing chamber & {$[12,19]$} \\
\hline & Sheep visceral peritoneum & $\begin{array}{l}10^{-3} \text { amil to apical, basolateral } \\
\text { sides }\end{array}$ & Ussing chamber & {$[13,19]$} \\
\hline & Human, sheep parietal pleura & $10^{-5}$ amil to apical side & Ussing chamber & [19] \\
\hline & Knockout mouse pleura & $2 \times 10^{-4}$ amil to pleural space, & pleural fluid clearance & {$[15]$} \\
\hline \multirow[t]{2}{*}{$\mathrm{Na}^{+}-\mathrm{K}^{+}$-ATPase } & Sheep visceral and parietal pleura & $\begin{array}{l}10^{-3} \text { ouabain to apical and } \\
\text { basolateral sides }\end{array}$ & Ussing chamber & [20] \\
\hline & Rabbit pleura & $\begin{array}{c}2 \times 10^{-4} \text { ouabain to apical, baso- } \\
\text { lateral sides }\end{array}$ & $\begin{array}{l}\text { measurement of the net rate of liquid } \\
\text { absorption }\end{array}$ & {$[21,22]$} \\
\hline $\mathrm{K}^{+}$channels & Human peritoneum, mesothelial cells & $\begin{array}{l}3 \times 10^{-3} \text { TEA, } 10^{-8} \text { IBTx }, 3 \times 10^{-4} \\
\mathrm{BaCl}_{2}, 2 \times 10^{-8} \text { TPQ, } 10^{-4} 4-\mathrm{AP}\end{array}$ & patch-clamp, RT-PCR & [24] \\
\hline \multirow[t]{2}{*}{$\mathrm{Ca}^{2+}$ channels } & $\begin{array}{l}\text { Rat pleural and pericardial mesothelial } \\
\text { cells }\end{array}$ & $10^{-6}$ nifedipine, $10^{-5}$ ryanodine & measurement of $\mathrm{Ca}^{2+}$, staining & [25] \\
\hline & Rat peritoneal mesothelial cells & & cell cGMP and $\mathrm{Ca}^{2+}, \mathrm{SEM}$ & [26] \\
\hline $\mathrm{Cl}^{-}$channels & $\begin{array}{l}\text { Human primary pleural mesothelioma } \\
\text { cells, MeT-5A cells }\end{array}$ & $10^{-4} \mathrm{NPPB}$ & patch-clamp, RT-PCR, staining & [27] \\
\hline $\begin{array}{l}\text { Voltage-gated } \mathrm{Na}^{+} \\
\text {channels }\end{array}$ & $\begin{array}{l}\text { Human pleural specimen, mesothe- } \\
\text { lioma cells }\end{array}$ & $10^{-6} \mathrm{TTX}$ & patch-clamp, RT-PCR & [24] \\
\hline Aquaporin 1 & Knockout mouse pleura & $1.1 \times 10^{-5} \mathrm{HgCl}_{2}$ & $\begin{array}{l}\text { permeability and clearance, RT-PCR, } \\
\text { staining. }\end{array}$ & {$[15,28]$} \\
\hline
\end{tabular}

Ref, references; amil, amiloride; TEA, tetraethylammonium; IBTx, iberiotoxin; TPQ, tertiapine-Q; 4-AP, 4-aminopyridine; NPPB, nitrophenylpropylamino benzoate; TTX, tetrodotoxin; SITS, 4-acetamido-4'-isothiocyanatostilbene-2,2'disulfonate; EIPA, ethylisopropyl amiloride; SEM, Scanning electron microscope; M/L, moles per liter; RT-PCR, Reverse transcription polymerase chain reaction; cGMP, guanosine-3',5'-cyclic monophosphate. 
Table 2. Antiport and Symport Systems in Mesothelial Cells

\begin{tabular}{|c|c|c|c|c|}
\hline $\mathrm{Na}^{+} / \mathrm{H}^{+}$exchanger & Rabbit pleura & $7 \times 10^{-4}$ amiloride & net rate of liquid absorption & {$[21,22,39]$} \\
\hline $\begin{array}{l}\mathrm{Cl}^{-} / \mathrm{HCO}_{3}^{-} \\
\text {exchanger }\end{array}$ & Rabbit pleura & $10^{-4}$ SITS & net rate of liquid absorption & {$[21,22]$} \\
\hline $\begin{array}{l}\mathrm{Na}^{+} \text {-glucose } \\
\text { transporter }\end{array}$ & Rabbit pleura and mesothelial cells & & western blot & [42] \\
\hline \multirow{2}{*}{$\begin{array}{c}\mathrm{Na}^{+}-/ \mathrm{K}^{+}-/ 2 \mathrm{Cl}^{-} \\
\text {transporter }\end{array}$} & Rabbit pleura & $10^{-4}$ bumetanide & net rate of liquid absorption & {$[22]$} \\
\hline & Rabbit pleura & $10^{-5}$ bumetanide & net rate of liquid absorption, $\mathrm{Na}^{+}$ions & [43] \\
\hline
\end{tabular}

SITS, 4-acetamido-4'-isothiocyanatostilbene-2,2'disulfonate; EIPA, ethylisopropyl amiloride; M/L, moles per liter; $\mathrm{pH}_{\mathrm{i}}$, intracellular $\mathrm{pH}$.

Very recently, Jiang and colleagues studied the amiloride-sensitive fluid transport pathway in pleura in vivo [15]. The $\beta_{2}$ adrenergic receptor agonist, terbutaline increased pleural isosmolar fluid absorption, which was inhibited by amiloride. Neither terbutaline nor amiloride affected osmotic water movement. Terbutaline has long been used clinically to effectively ameliorate pulmonary edema by up-regulating $\mathrm{ENaC}$ activity and thereby expediting edematous liquid clearance $[16,17]$. These exciting observations support the scenario that $\mathrm{ENaC}$ channels are functionally expressed in pleural tissues and contribute to pleural fluid re-absorption. However, it should be remembered that $\mathrm{ENaC}$ expression in mesothelial cells has not been systematically characterized at the mRNA and protein levels. We recently detected expression of $\alpha-, \beta-, \gamma-$, and $\delta \mathrm{ENaC}$ subunits at the mRNA and protein levels in M9K cells, a human pleural mesothelial cell line and mouse pleural tissues [18]. More excitingly, an amiloride-sensitive, ENaC-like short-circuit current was recorded in mouse pleural tissues and confluent M9K monolayers mounted in Ussing chamber [18]. The systematic biophysical and pharmacological features of this ENaC-like channel are being characterized in our laboratory currently (Nie et al. unpublished data).

\section{I-2. $\mathrm{Na}^{+}-\mathrm{K}^{+}$-ATPase and $\mathrm{Ca}^{2+}$-ATPase}

In epithelial cells, $\mathrm{Na}^{+}-\mathrm{K}^{+}$-ATPase is located at the basolateral membrane and extrudes cytosolic sodium ions, working together with apically situated $\mathrm{ENaC}$ channels to serve as a vital vectorial salt re-absorption pathway. This enzyme transports two potassium ions into the cell and transports three sodium ions out of the cell for each molecule of ATP hydrolyzed. Pharmacological evidence based on the use of specific inhibitors, ouabain supports the conclusion that $\mathrm{Na}^{+}-$ $\mathrm{K}^{+}$-ATPase is expressed in the pleura of sheep and rabbits. [20-22]. According to these results, there may be two subtypes of mesothelial cells in the pleura. In the first group of cells, the $\mathrm{Na}^{+}-\mathrm{K}^{+}$-ATPase is likely expressed only in the mucosal side and therefore should pump $\mathrm{Na}^{+}$ions out of the pleural space. While in the second group of cells, the $\mathrm{Na}^{+}-$ $\mathrm{K}^{+}$-ATPase is located in the serosal side, which could be involved in recycling $\mathrm{K}^{+}$and possibly other unknown function. Intriguingly, $\mathrm{Na}^{+}-\mathrm{K}^{+}$-ATPase has also been discovered on the apical membrane in other epithelial cells, for example, in the chordoid plexus $[29,30]$ and retinal pigment epithelium $[31,32]$. These mechanisms are probably involved in maintaining an adequate volume and physiological composition of the pleural fluid and of mesothelial cell cytoplasm [20, 21]. Morphologically (Fig. 2), two different kinds of cells exist in the pleural mesothelium: the flat cells (type I), which are the most numerous and have well developed tight junctions, and the cuboidal cells (type II), which have less developed tight junctions [21, 33, 34]. However, the diverse distribution of $\mathrm{Na}^{+}-\mathrm{K}^{+}$-ATPase and of other transport systems in these two subtypes of cells still needs to be clarified.

Given ouabain was used as a specific blocker for $\mathrm{Na}^{+}-\mathrm{K}^{+}-$ ATPase in these studies, and the location of $\mathrm{Na}^{+}-\mathrm{K}^{+}$-ATPase has not been verified immunocytochemically, we should

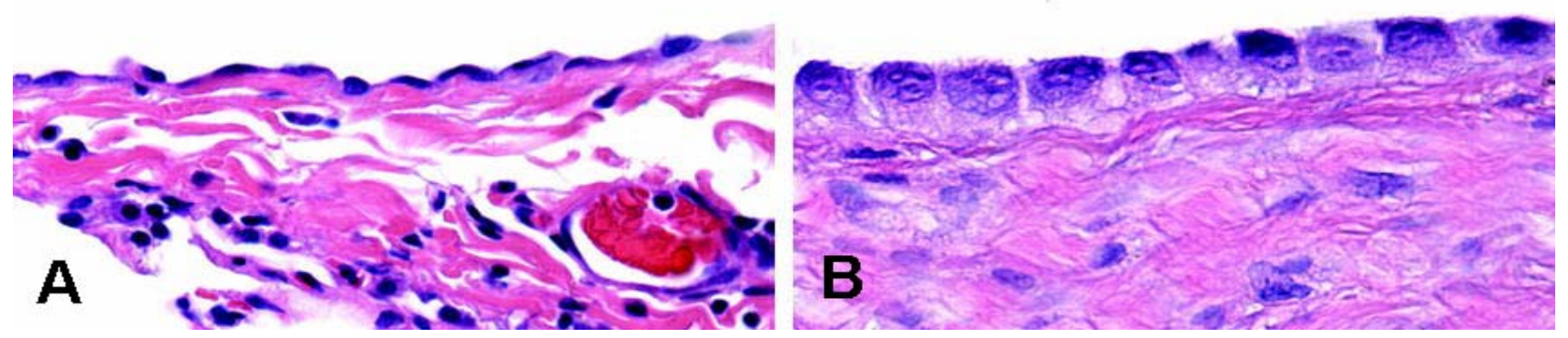

Fig. (2). Histology of human pleural mesothelial cells (adapted from Cagle and Churg with permission from Archives of Pathology \& Laboratory Medicine. Copyright 2005. College of American Pathologists [34]). A. Type I mesothelial cells. High-power view shows flat, inconspicuous normal mesothelial cells lining the visceral pleural surface (hematoxylin-eosin, original magnification $\times 300$ ). B. Type II mesothelial cells. A more conspicuous layer of relatively bland cuboidal cells regularly spaced along the pleural surface (hematoxylin-eosin, original magnification $\times 350$ ). 
keep in mind that ouabain-inhibitable $\mathrm{H}^{+}-\mathrm{K}^{+}$-ATPase $\alpha$ subunit may co-exist $[35,36] . \mathrm{H}^{+}-\mathrm{K}^{+}$-ATPase has been found in re-absorptive epithelial tissues, including kidney and gastrointestinal tract $[36,37]$. It has been reported $\mathrm{H}^{+}-\mathrm{K}^{+}-$ ATPase can form a hybrid with $\mathrm{Na}^{+}-\mathrm{K}^{+}$-ATPase [36]. However, Little is known if $\mathrm{H}^{+}-\mathrm{K}^{+}$-ATPase is expressed in the apical and basolateral membranes in mesothelia.

Caveolar accumulation of the plasmalemmal $\mathrm{Ca}^{2+}$ ATPase by electron microscopy immunolabelling was seen in mesothelial cells [23]. In addition to caveolae attached to the apical and basolaterial membranes, vesicles deep in the cytoplasm in mesothelial cells were labeled for the plasmalemmal $\mathrm{Ca}^{2+}$ pump. It is not clear whether the cytoplasmic vesicles in this type of cells are connected to the surface membrane. In the mesothelial cells, the majority of the labeling in the caveolae was observed along the cytoplasmic surface of the plasma membrane, with relatively few gold particles seen on the exoplasmic side. This distribution is consistent with the molecular structure of the plasmalemmal $\mathrm{Ca}^{2+}$ ATPase; it traverses the lipid bilayer multiple times but most of the molecular mass is thought to exist in the cytoplasm [23]. It is inferred that the smooth plasmalemmal invagination is an apparatus specialized for $\mathrm{Ca}^{2+}$ intake and extrusion from the cytoplasm.

\section{I-3. Potassium Channels}

Potassium channels are predominately expressed in the interstitial membrane in absorptive epithelium. By comparing normal and neoplastic mesothelial cells, Fulgenzi et al. assessed possible differences in the expression patterns of $\mathrm{K}^{+}$ channels between these two types of cells [24]. Voltagegated $\mathrm{K}^{+}$currents, an inward rectified fraction $\left(\mathrm{K}_{\mathrm{IR}}\right)$, and most prominent $\mathrm{K}^{+}$current $\left(\operatorname{maxiK}_{\mathrm{Ca}}\right)$, which could be measured in most normal mesothelial cells, were not found in neoplastic mesothelial cells. The lack of $\mathrm{K}^{+}$efflux pathways through voltage-gated $\mathrm{K}^{+}$channels may explain the wellknown resistance to chemotherapy of primary mesotheliomas, for $\mathrm{K}^{+}$efflux is an early event in the apoptotic process, and a decrease in intracellular $\mathrm{K}^{+}$is a prerequisite for apoptosis triggering and progression [38].

\section{I-4. Calcium Channels}

Voltage-dependent $\mathrm{Ca}^{2+}$ channels have been found in mesothelial cells. Ito et al. studied the mechanisms of cytosolic $\mathrm{Ca}^{2+}$ mobilization in mesothelial cells and found that $\mathrm{Ca}^{2+}$ influx, which is carried by L-type voltage-dependent $\mathrm{Ca}^{2+}$ channels and receptor-operated $\mathrm{Ca}^{2+}$ channels, is critical for increasing cytosolic $\mathrm{Ca}^{2+}[25]$. It is well-known that elevated intracellular $\mathrm{Ca}^{2+}$ ion acts as a second messenger and initiates numerous important cellular events. In addition, Factin-staining studies have clearly shown a regulatory role for cytosolic $\mathrm{Ca}^{2+}$ in cytoskeleton assembly in mesothelial cells [25].

Recently, it has been reported that nitric oxide (NO) can decrease cytosolic $\mathrm{Ca}^{2+}$ in the rat peritoneal mesothelial cells through the NO-cGMP signaling pathway [26]. This process is associated with the L-type voltage-gated $\mathrm{Ca}^{2+}$ channel. On the other hand, NO also enlarges the opening area of the lymphatic stomata and thereby enhances lymph drainage via the NO-cGMP-Ca ${ }^{2+}$ signaling pathway [26].

\section{I-5. Chloride Channels}

Chloride channels, for example the cystic fibrosis transmembrane conductance regulator (CFTR), in the apical membrane of epithelial cells, are predominate fluid secretion mediators. Meyer and colleagues demonstrated the presence of a regulatory volume decrease channel (RVDC), which is also active in isotonic conditions in mesothelioma cells [27]. The number of active anion channels increases in hypotonic conditions, in concert with enhanced swelling-activated chloride current (ICln) expression in the cell membrane. This latter event could be the result of activation of the RVDC. Whether RVDC is due to or regulated by ICln is still a matter of debate [44]. Further investigation of the differences between chloride channel properties in mesothelial and mesothelioma cells is warranted since the RVDC may be involved in the regulation of both the progress of the cell cycle and of cell migration and apoptosis. More importantly, these studies could prove useful in the diagnosis and/or treatment of mesothelioma, a cancer type particularly resistant to chemotherapy [45].

In marked contrast to the extensive studies on CFTR in epithelial cells, none have been reported in mesothelial cells. This is despite the fact that cystic fibrosis patients generally have chronic inflammation of pleural cavity and adhesions occur following lung transplantation [46].

\section{I-6. Voltage-Gated Sodium Channels}

Increased activity of voltage-gated sodium channels in the plasma membrane of neoplastic cells compared to their normal counterparts has been reported in epithelial cells [47]. Similarly, Fulgenzi et al. have reported that an inward rectified, voltage-gated sodium channel is expressed in mesothelioma cells. This is not detected in normal mesothelial cells. Furthermore blockade of the voltage-gated sodium channel with TTX decreased mesothelioma cell migration in in vitro motility assays, but had little effect on cell viability, proliferation, or apoptosis progression triggered by UV exposure. These studies suggest that the TTX-sensitive voltage-gated $\mathrm{Na}^{+}$currents might facilitate increased motility of neoplastic cells, a feature often associated with the malignant phenotype [24].

\section{I-7. Aquaporins}

The aquaporins (AQPs) are a family of small membranespanning proteins (monomer size, $30 \mathrm{kDa}$ ) that are expressed in the plasma membranes of many types of cells involved in fluid transport. The AQP family of water channels comprises 10 proteins cloned from mammals and many more from amphibians, plants, yeast, bacteria, and various lower organisms. Several of the mammalian aquaporins (e.g., AQP1, AQP2, AQP4, and AQP5) appear to be highly selective for the passage of water, whereas others (recently termed aquaglyceroporins) also transport glycerol (e.g., AQP3 and AQP8) and even larger solutes (AQP9) [48]. Aquaporin water channels play an important role in the regulation of dynamic fluid homeostasis [49]. Water movement across aquaporins can be driven by osmotic, oncotic, or hydrostatic forces.

AQPs have been found to be localized in mesothelial cells [50]. AQP1 was expressed in diaphragmatic, visceral, 
and parietal pleura [28], indicating that AQP1 may play a role in fluid dynamics in the pleural spaces. Pleural osmotic water permeability in AQP1 knockout mice was examined. Compared to normal control animals, the deletion of AQP1 significantly reduced pleural osmotic water permeability, but not isosmolar liquid pleural absorption [15]. These studies provide compelling evidence that AQP1 does indeed govern pleural fluid turnover.

\section{ANTIPORT AND SYMPORT SYSTEMS}

\section{II-1. Antiport Systems (Exchangers)}

\section{II-1-1. $\mathrm{Na}^{+}$-Dependent $\mathrm{Cl} / \mathrm{HCO}_{3^{-}}$Exchanger}

Indirect evidence for the existence of solute-coupled fluid absorption from the pleural space of rabbits has been provided by measuring the net rate of fluid absorption (Jnet) of Ringer hydrothoraces in the presence or absence of inhibitors of the $\mathrm{Na}^{+} / \mathrm{H}^{+}-\mathrm{Cl}^{-} / \mathrm{HCO}_{3}{ }^{-}$coupled exchanger (4-acetamido4'- isothiocyanatostilbene-2,2'disulfonate $0.1 \mathrm{mM}$, bumetanide $0.1 \mathrm{mM}$, and amiloride $0.7 \mathrm{mM}$ ) [39]. In the presence of these inhibitors, Jnet was markedly smaller than in the control ones. These findings suggested the occurrence of a solute-coupled fluid absorption from the pleural space, consistent with the involvement of a $\mathrm{Na}^{+} / \mathrm{H}^{+}-\mathrm{Cl}^{-} / \mathrm{HCO}_{3}{ }^{-}$co- exchanger located on the serosal side of the pleural mesothelium $[21,22]$. So far, several sodium-dependent $\mathrm{HCO}_{3}{ }^{-}$ transport isoforms have been cloned [51, 52]. The molecular basis of this coupled exchanger activity in pleural tissues requires follow-up studies.

\section{II-1-2. $\mathrm{Na}^{+} / \mathrm{H}^{+}$Exchanger}

Using a pH-sensitive fluorescent probe, 2',7'-bis(2carboxyethyl)-5(6)-carboxyfluorescein, Liaw and co-workers observed that PKC activation is one of the downstream signals in the epidermal growth factor-induced activation of the $\mathrm{Na}^{+} / \mathrm{H}^{+}$exchanger in primary cultures of human pleural mesothelial cells [40]. 12-O-tetradecanoylphorbol 13-acetate stimulates the ethylisopropyl amiloride-sensitive $\mathrm{Na}^{+} / \mathrm{H}^{+}$exchanger, and subsequent alkalosis can be blocked by the PKC inhibitors chelerythrine and staurosporine. Taken together, these reports suggest that PKC is indeed involved in the activation of the $\mathrm{Na}^{+} / \mathrm{H}^{+}$-exchanger in mesothelial cells.

\section{II-2. Symport Systems (Co-Transporters)}

\section{II-2-1. $\mathrm{Na}^{+}$-Glucose Co-Transporter}

Evidence for a $\mathrm{Na}^{+}$-glucose co-transporter in the mesothelium has also been provided through use of $0.5-2 \mathrm{ml}$ albumin-Ringer hydrothoraces with a specific inhibitor, phloridzin (0.1-1 mM) [41]. The decrease in net rate of fluid absorption in pleural space produced by phloridzin suggests that a $\mathrm{Na}^{+}$-glucose co-transporter operates on the luminal side of the pleural mesothelium and this contributes to the solute-coupled pleural fluid absorption. Subsequently the same group found that the $\mathrm{Na}^{+}$-glucose co-transporter activity is coordinated with $\mathrm{Na}^{+}$-dependent $\mathrm{HCO}_{3}{ }^{-}$exchanger activity on the luminal side under physiologic conditions [39]. Owing to the morphological similarity between pleural visceral and parietal mesothelial cells, it seemed likely that the solute-coupled fluid absorption occurred on both sides. Indeed, the most recent results clearly provided molecular evidence for the $\mathrm{Na}^{+}$-glucose co-transporter both in the visceral and parietal pleural mesothelium [42].

\section{II-2-2. $\mathrm{Na}^{+}-\mathrm{K}^{+}-2 \mathrm{Cl}$ Co-Transporter}

Zocchi et al. found that in hydrothoraces with amiloride plus terbutaline, a $\beta_{2}$ adrenergic receptor agonist, the net rate of fluid absorption in pleural space was greater than in those with amiloride alone [43]. This observation indicates that terbutaline activates an amiloride-insensitive mechanism for $\mathrm{Na}^{+}$transport across the luminal membrane of the mesothelium. Bumetanide, a potent $\mathrm{Na}^{+}-\mathrm{K}^{+}-2 \mathrm{Cl}^{-}$co-transport inhibitor, completely blocked the terbutaline-induced increase in the net rate of fluid absorption. Obviously, terbutaline increased the albumin-Ringer net absorption rate either through activation of the $\mathrm{Na}^{+}-\mathrm{K}^{+}-2 \mathrm{Cl}^{-}$co-transport system or a $\mathrm{Na}^{+}-\mathrm{Cl}^{-}$symporter [43]. Furthermore, Ye et al. recently found $\beta$ adrenogic receptor stimulation by endogenous fetal epinephrine increased fetal distal airspace fluid clearance in timed-pregnant guinea pigs and that this involved bumetanide-sensitive ion transport, i.e., the $\mathrm{Na}^{+}-\mathrm{K}^{+}-2 \mathrm{Cl}^{-}$cotransporter [53].

\section{PHYSIOLOGICAL AND CLINICAL RELEVANCE}

Irrespective of their anatomical origin, peritoneal, pleural, and pericardial mesothelial cells have shown similarities in their functional properties [54]. To provide a non-adhesive frictionless protective barrier that facilitates movement of opposing tissues and organs within the serous cavities, the volume and components of the fluid in pleura, pericardium, and peritonium must be tightly regulated. For example, the volume of pleural fluid results from a balance of fluid inflow and outflow, occurring by Starling forces (assuming filtration through the parietal, and absorption through the visceral mesothelium), amiloride-sensitive lymphatic drainage through the parietal pleura stomas, and electrolyte-coupled fluid absorption through the mesothelium of both sides [55, 56]. In humans, the balanced rate of fluid secretion and absorption in the steady state is $\sim 0.01 \mathrm{ml} \mathrm{kg}^{-1} \mathrm{~h}^{-1}$ [57]. Compelling evidence, as reviewed in this manuscript, confirms the critical role played by mesothelial cells in fluid transport across the serosal cavities. In addition, mesothelial cells play a central role in antigen presentation, inflammation and tissue repair, coagulation and fibrinolysis, and tumor cell adhesion within the serosal cavities [54].

Pleural effusions, pericardial effusions, and ascites are all common medical problems and significant causes of morbidity. The pathogenesis of these diseases may involve increased transmesothelial membrane filtration, reduced fluid reabsorptive transport, pulmonary capillary pressure, decreased negative intrapleural or oncotic pressure, or obstructed lymphatic flow which is a most common complication in mesothelioma, bacterial infection, and tuberculosis [58]. For example, most patients with earlier stage mesothelioma present with pleural effusions [59]. Ion transport systems in mesothelial cells, such as voltage-gated $\mathrm{Na}^{+}$channels [24], not only regulate the balance of fluid turnover and absorption, but also relate to cell proliferation.

\section{PROSPECTIVE}

The control of both the volume and composition of the fluid in pleural, pericardial, and peritoneal cavities is affected by a number of mechanisms [3]. Until recently the potential contribution of aforementioned ion electrolyte transport systems in this review, to the cavity fluid turnover 
and re-absorption have been neglected. Increasing evidence has now accumulated to support the contention that active transmesothelial transport does play an important role [12, $13,20]$. However, further studies using state-of-the-art techniques, such as genetic knockout models, are still required to unequivocally discern the role played by these transport systems under physiological and pathological conditions.

\section{ACKNOWLEDGMENTS}

This work is supported by NIH grant HL 87017. We thank Dr. Mark AL Atkinson for the critical reading of the manuscript.

\section{REFERENCES}

[1] Lai-Fook SJ. Pleural mechanics and fluid exchange. Physiol Rev 2004; 84(2): 385-410.

[2] Yung S, Li FK, Chan TM. Peritoneal mesothelial cell culture and biology. Perit Dial Int 2006; 26(2): 162-73.

[3] Zocchi L. Physiology and pathophysiology of pleural fluid turnover. Eur Respir J 2002; 20(6): 1545-58.

[4] Canessa CM, Schild L, Buell G, et al. Amiloride-sensitive epithelial $\mathrm{Na}^{+}$channel is made of three homologous subunits. Nature 1994; 367(6462): 463-7.

[5] Lingueglia E, Voilley N, Waldmann R, Lazdunski M, Barbry P. Expression cloning of an epithelial amiloride-sensitive $\mathrm{Na}^{+}$channel. A new channel type with homologies to Caenorhabditis elegans degenerins. FEBS Lett 1993; 318(1): 95-9.

[6] Waldmann R, Champigny G, Bassilana F, Voilley N, Lazdunski M. Molecular cloning and functional expression of a novel amiloridesensitive $\mathrm{Na}^{+}$channel. J Biol Chem 1995; 270(46): 27411-4.

[7] Kellenberger S, Schild L. Epithelial sodium channel/degenerin family of ion channels: a variety of functions for a shared structure. Physiol Rev 2002; 82(3): 735-67.

[8] McNicholas CM, Canessa CM. Diversity of channels generated by different combinations of epithelial sodium channel subunits. J Gen Physiol 1997; 109(6): 681-92.

[9] Teiwes J, Toto RD. Epithelial sodium channel inhibition in cardiovascular disease. A potential role for amiloride. Am J Hypertens 2007; 20(1): 109-17.

[10] Kleyman TR, Cragoe EJ Jr. Amiloride and its analogs as tools in the study of ion transport. J Membr Biol 1988; 105(1): 1-21.

[11] Kleyman TR, Cragoe EJ Jr. The mechanism of action of amiloride. Semin Nephrol 1988; 8(3): 242-8.

[12] Stefanidis I, Liakopoulos V, Kourti P, et al. Amiloride-sensitive sodium channels on the parietal human peritoneum: evidence by ussing-type chamber experiments. ASAIO J 2007; 53(3): 335-8.

[13] Zarogiannis S, Kourti P, Hatzoglou C, et al. Influence of the sodium transport inhibition by amiloride on the transmesothelial resistance of isolated visceral sheep peritoneum. Adv Perit Dial 2005; 21: $5-8$.

[14] Zarogiannis S, Hatzoglou C, Stefanidis I, et al. Comparison of the electrophysiological properties of the sheep isolated costal and diaphragmatic parietal pleura. Clin Exp Pharmacol Physiol 2007; 34(1-2): 129-31.

[15] Jiang J, Hu J, Bai C. Role of aquaporin and sodium channel in pleural water movement. Respir Physiol Neurobiol 2003; 139(1): 83-8.

[16] Sakuma T, Folkesson HG, Suzuki S, Okaniwa G, Fujimura S, Matthay MA. Beta-adrenergic agonist stimulated alveolar fluid clearance in ex vivo human and rat lungs. Am J Respir Crit Care Med 1997; 155(2): 506-12.

[17] Sartori C, Fang X, McGraw DW, et al. Selected contribution: longterm effects of beta(2)-adrenergic receptor stimulation on alveolar fluid clearance in mice. J Appl Physiol 2002; 93(5): 1875-80.

[18] Nie HG, Tucker T, Su XF, Smith PR, Idell S, Ji HL. Expression of four ENaC subunits in human mesothelial cells. Am J Respir Crit Care Med 2008; 177(Suppl): A800.

[19] Sarkos S, Hatzoglou C, Dahabre J, Gourgoulianis KI, Molyvdas PA. Effect of amiloride in human and sheep parietal pleura. Respir Physiol Neurobiol 2002; 132(2): 233-7.

[20] Hatzoglou CH, Gourgoulianis KI, Molyvdas PA. Effects of SNP, ouabain, and amiloride on electrical potential profile of isolated sheep pleura. J Appl Physiol 2001; 90(4): 1565-9.
[21] Zocchi L, Agostoni E, Cremaschi D. Electrolyte transport across the pleura of rabbits. Respir Physiol 1991; 86(1): 125-38.

[22] Agostoni E, Zocchi L. Solute-coupled liquid absorption from the pleural space. Respir Physiol 1990; 81(1): 19-27.

[23] Fujimoto T. Calcium pump of the plasma membrane is localized in caveolae. J Cell Biol 1993; 120(5): 1147-57.

[24] Fulgenzi G, Graciotti L, Faronato M, et al. Human neoplastic mesothelial cells express voltage-gated sodium channels involved in cell motility. Int J Biochem Cell Biol 2006; 38(7): 1146-59.

[25] Ito K, Kuwahara M, Sugano S. Role of intra- and extracellular calcium stores in mesothelial cell response to histamine. Am J Physiol 1995; 268(1 Pt 1): L63-70.

[26] Li YY, Li JC. Effects of nitric oxide on peritoneal lymphatic stomata and lymph drainage via NO-cGMP-Ca ${ }^{2+}$ pathway. Acta Physiol Sin 2005; 57(1): 45-53.

[27] Meyer G, Rodighiero S, Guizzardi F, et al. Volume-regulated $\mathrm{Cl}^{-}$ channels in human pleural mesothelioma cells. FEBS Lett 2004; 559(1-3): 45-50.

[28] Song Y, Yang B, Matthay MA, Ma T, Verkman AS. Role of aquaporin water channels in pleural fluid dynamics. Am J Physio Cell Physiol 2000; 279(6): C1744-50.

[29] Masuzawa T, Ohta T, Kawamura M, Nakahara N, Sato F. Immunohistochemical localization of $\mathrm{Na}^{+}, \mathrm{K}^{+}$-ATPase in the choroid plexus. Brain Res 1984; 302(2): 357-62.

[30] Masuzawa T, Ohta T, Kawakami K, Sato F. Immunocytochemical localization of $\mathrm{Na}^{+}, \mathrm{K}^{+}$-ATPase in the canine choroid plexus. Brain 1985; 108 ( Pt 3): 625-46.

[31] Rizzolo LJ, Zhou S. The distribution of $\mathrm{Na}^{+}, \mathrm{K}^{+}$-ATPase and 5A11 antigen in apical microvilli of the retinal pigment epithelium is unrelated to $\alpha$-spectrin. J Cell Sci 1995; 108 ( Pt 11): 3623-33.

[32] Rajasekaran SA, Hu J, Gopal J, et al. Na, K-ATPase inhibition alters tight junction structure and permeability in human retinal pigment epithelial cells. Am J Physiol Cell Physiol 2003; 284(6): C1497-507.

[33] Mutsaers SE. The mesothelial cell. Int J Biochem Cell Biol 2004; 36(1): 9-16.

[34] Cagle PT, Churg A. Differential diagnosis of benign and malignant mesothelial proliferations on pleural biopsies. Arch Pathol Lab Med 2005; 129(11): 1421-7.

[35] Pestov NB, Romanova LG, Korneenko TV, et al. Ouabainsensitive H,K-ATPase: tissue-specific expression of the mammalian genes encoding the catalytic alpha subunit. FEBS Lett 1998; 440(3): 320-4.

[36] Rajendran VM, Sangan P, Geibel J, Binder HJ. Ouabain-sensitive $\mathrm{H}, \mathrm{K}-\mathrm{ATPase}$ functions as $\mathrm{Na}, \mathrm{K}-\mathrm{ATPase}$ in apical membranes of rat distal colon. J Biol Chem 2000; 275(17): 13035-40.

[37] Beltowski J, Wojcicka G. Spectrophotometric method for the determination of renal ouabain-sensitive $\mathrm{H}^{+}, \mathrm{K}^{+}$-ATPase activity. Acta Biochim Pol 2002; 49(2): 515-27.

[38] Remillard CV, Yuan JX. Activation of $\mathrm{K}^{+}$channels: an essential pathway in programmed cell death. Am J Physiol Lung Cell Mol Physiol 2004; 286(1): L49-67.

[39] Agostoni E, Zocchi L. Mechanical coupling and liquid exchanges in the pleural space. Clin Chest Med 1998; 19(2): 241-60.

[40] Liaw YS, Yang PC, Yu CJ, et al. PKC activation is required by EGF-stimulated $\mathrm{Na}^{+}-\mathrm{H}^{+}$exchanger in human pleural mesothelial cells. Am J Physiol 1998; 274(5 Pt 1): L665-72.

[41] Zocchi L, Agostoni E, Raffaini A. Effect on phloridzin on net rate of liquid absorption from the pleural space of rabbits. Exp Physiol 1996; 81(6): 957-67.

[42] Sironi C, Bodega F, Porta C, Zocchi L, Agostoni E. Expression of $\mathrm{Na}^{+}$-glucose cotransporter (SGLT1) in visceral and parietal mesothelium of rabbit pleura. Respir Physiol Neurobiol 2007; 159(1): 68-75.

[43] Zocchi L, Agostoni E, Cremaschi D. Beta-agonist activation of an amiloride-insensitive transport mechanism in rabbit pleura. Respir Physiol 1995; 100(1): 7-13.

[44] Emma F, Breton S, Morrison R, Wright S, Strange K. Effect of cell swelling on membrane and cytoplasmic distribution of pICln. Am J Physiol 1998; 274(6 Pt 1): C1545-51.

[45] Khalil MY, Mapa M, Shin HJ, Shin DM. Advances in the management of malignant mesothelioma. Curr Oncol Rep 2003; 5(4): 334-41.

[46] Tomashefski JF Jr., Dahms B, Bruce M. Pleura in pneumothorax. Comparison of patients with cystic fibrosis and idiopathic spontaneous pneumothorax. Arch Pathol Lab Med 1985; 109(10): 910-6. 
[47] Ding Y, Djamgoz MB. Serum concentration modifies amplitude and kinetics of voltage-gated $\mathrm{Na}^{+}$current in the Mat-LyLu cell line of rat prostate cancer. Int J Biochem Cell Biol 2004; 36(7): 124960.

[48] Verkman AS, Mitra AK. Structure and function of aquaporin water channels. Am J Physiol Renal Physiol 2000; 278(1): F13-28.

[49] Bai C, Fukuda N, Song Y, Ma T, Matthay MA, Verkman AS. Lung fluid transport in aquaporin-1 and aquaporin-4 knockout mice. J Clin Invest 1999; 103(4): 555-61.

[50] Twardowski ZJ. Pathophysiology of peritoneal transport. Contrib Nephrol 2006; 150: 13-9.

[51] Wang Z, Conforti L, Petrovic S, Amlal H, Burnham CE, Soleimani M. Mouse Na+: HCO3- cotransporter isoform NBC-3 (kNBC-3): cloning, expression, and renal distribution. Kidney Int 2001; 59(4): 1405-14.

[52] Sun XC, Bonanno JA. Identification and cloning of the $\mathrm{Na} / \mathrm{HCO}$ (3-) cotransporter (NBC) in human corneal endothelium. Exp Eye Res 2003; 77(3): 287-95.
[53] Ye X, Norlin A, Folkesson HG. Stimulation of distal airspace fluid clearance in guinea pigs involves bumetanide-sensitive ion transport. Am J Obstet Gynecol 2004; 191(1): 340-5.

[54] Mutsaers SE. Mesothelial cells: their structure, function and role in serosal repair. Respirology 2002; 7(3): 171-91.

[55] Miserocchi G. Physiology and pathophysiology of pleural fluid turnover. Eur Respir J 1997; 10(1): 219-25.

[56] Mitrouska I, Bouros D. The trans-exudative pleural effusion. Chest 2002; 122(5): 1503-5.

[57] Wiener-Kronish JP, Albertine KH, Licko V, Staub NC. Protein egress and entry rates in pleural fluid and plasma in sheep. $\mathrm{J}$ Appl Physiol 1984; 56(2): 459-63.

[58] Medford A, Maskell N. Pleural effusion. Postgrad Med J 2005; 81(961): 702-10

[59] Russo P, Catassi A, Malacarne D, et al. Tumor necrosis factor enhances SN38-mediated apoptosis in mesothelioma cells. Cancer 2005; 103(7): 1503-18

Received: February 25, 2008

Revised: April 17, 2008

Accepted: April 17, 2008

(c) Ji and Nie; Licensee Bentham Open.

This is an open access article distributed under the terms of the Creative Commons Attribution License (http://creativecommons.org/license/by/2.5/), which permits unrestrictive use, distribution, and reproduction in any medium, provided the original work is properly cited. 